\title{
Study of dephosphorylated 2'-5'-linked oligoadenylates impact on apo-S100A1 protein conformation by heteronuclear NMR and circular dichroism
}

\author{
O. Yu. Skorobogatov ${ }^{1}$, D. N. Lozhko ${ }^{1}$ I. Yu. Zhukov ${ }^{2,3}$, O. V. Kozlov ${ }^{1}$ Z. Yu. Tkachuk ${ }^{1}$ \\ ${ }^{1}$ Institute of Molecular Biology and Genetics, NAS of Ukraine \\ 150, Akademika Zabolotnoho Str., Kyiv, Ukraine, 03680 \\ ${ }^{2}$ Institute of Biochemistry and Biophysics, Polish Academy of Sciences \\ 5a, Pawinskiego Str., Warsaw, Poland, 02-106 \\ ${ }^{3}$ NanoBioMedical Centre, Adam Mickiewicz University \\ 85, Umultowska Str., Poznan, Poland, 61-614 \\ skorobogatov.alx@gmail.com
}

Low molecular weight natural mediators, 2'-5'-linked oligoadenylates, play an important role in interferon-ba-
sed antiviral mechanism; participate in growth, apoptosis and other important cellular processes. Taking into
account their concentration within living cells, the 2'-5'A oligoadenylates may act as additional biologically acti-
ve substrates, capable of regulating the S100A1 protein functioning in vivo. Aim. Find the evidence for the interac-
tion of human apo-S100A1 with 2'-5'-linked oligoadenylates. Methods. Using the circular dichroism (CD) and
heteronuclear NMR spectroscopy. Results. The obtained results demonstrated the occurrence of the secondary
structure changes in human S100A1 protein upon the interaction with 2'-5'-linked oligoadenylates as well as indi-
cated specific residues involved in this process. Conclusions. Our study points to the 2'-5'-linked oligoadenylates
as possible additional elements of the complex system of fine regulation of the C Cat--signal transduction pathway in
human cells.

Keywords: 2'-5'-linked oligoadenylates, S100A1.

Introduction. Triphosphorylated 2'-5'-linked oligoadenylates, which can be defined by the general formula $\operatorname{ppp}\left(2^{\prime}-5^{\prime}\right) \mathrm{A}_{n}$, are being synthesized in the cell through interferon-induced enzyme - 2'-5'-oligoadenylate synthase (OAS). These compounds play a key role in the antiviral innate immunity mechanism, participate in the cell differentiation and apoptosis processes, at the same time being involved in diabetes and atherosclerosis pathogenesis. It was demonstrated, that they can be used as effective therapeutic compounds for oncology and hematology treatment $[1,2]$. Their biological activity is mainly related to the ribonuclease L (RNase L) activation: only phosphorylated 2'-5'-linked oligoadenylates are capable of activating the enzyme due to the presence of phosphate groups though. dephosphorylated, or

(c) Institute of Molecular Biology and Genetics, NAS of Ukraine, 2014 so-called «core» 2'-5'-linked oligoadenylates, do not bind to RNase L thus leaving the enzyme inactive [1-3].

The long-term research of 2'-5'-linked oligoadenylates is based on the «interferon hypothesis» of biological activity [1-4]. It assumes that the antiviral activity of these compounds is based on the formation of phosphorylated 2'-5'-linked oligoadenylates and further activation of RNase L, which specifically cleaves viral mRNAs, therefore rendering their antiviral properties. Nevertheless, phosphorylated oligoadenylates possess a low stability within the cell: they are cleaved by phosphorylases, thus forming «core» oligoadenylates, which display a set of other activities that have nothing to do with the interferon-RNase L system. In particular, 2'5'-linked triadenylates $\left(2^{\prime}-5^{\prime} \mathrm{A}_{3}\right)$ and their analogues possess cardio protector potential and may act as graft versus host disease (GVHD) inhibitors [5]. It is worth 


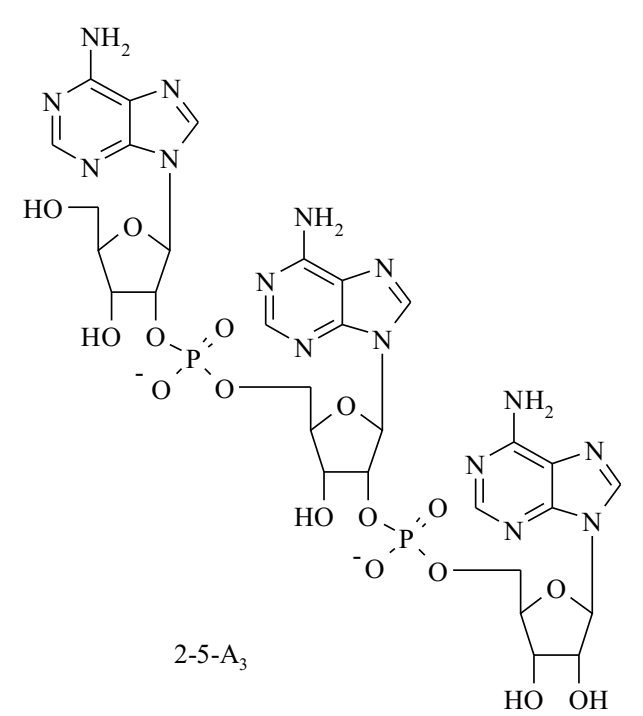

mentioning, that these compounds are also capable of executing the inhibiting effect on smooth muscle contraction [6].

The biological action of «core» $2^{\prime}-5{ }^{\prime} \mathrm{A}_{3}$ is not fully understood yet. Up to now, all target proteins are unknown. Our previous experiments identified a set of protein targets, with which the «core» $2^{\prime}-5^{\prime} \mathrm{A}_{3}$ and its analogues interact: strong binding to albumin and interferon and weak binding to immunoglobulin were demonstrated [7]. In order to investigate the ability of «core» $2^{\prime}-5$ ' $\mathrm{A}_{3}$ to interact with $\alpha$-interferon - the key protein of 2'-5'OAS/RNAase L system, responsible for antiviral cell defense - MALDI-TOF mass spectrometry was applied. It was shown, that naturally occurring $2^{\prime}-5^{\prime} \mathrm{A}_{3}$ and its epoxy-modified analogue (2'-5' $\mathrm{A}_{3}$-epo) bind to a-interferon, so $3^{\prime}-5$ '-linked triadenylate does. Simultaneous binding of up to five ligand molecules was demonstrated [8].

It is a matter of common knowledge that $\mathrm{Ca}^{2+}$ signal transduction is an essential mechanism, ensuring various cell processes regulation. Multifunctional $\mathrm{Ca}^{2+}$-transducing protein Calmodulin $(\mathrm{CaM})$ is one of the key proteins involved in it. As it has recently been shown in our group, native 2'-5' $\mathrm{A}_{3}$ binding to human $\mathrm{CaM}$ caused an alteration of its functional profile [9]. The experimental data revealed considerable (2-3 times) increase of its $\mathrm{Ca}^{2+}$ affinity upon interaction with «core $« 2^{\prime}-5{ }^{\prime} \mathrm{A}_{3}$, its epoxy and 3'-cordycepin modified analogues.

Using these data as a background, we decided to perform a study, focused on another $\mathrm{Ca}^{2+}$-binding protein, human S100A1. It is the protein with known acti- vity during neurological disorders and several types of cancer; its expression level serves as one of the key indicators for heart failure [10,11]. As shown recently, the S100A1 interacts with ryanodine receptor (RyR) in heart (RyR1) and skeletal (RyR2) muscles [12]. The S100A1 shares with CaM exactly the same binding site to interact with RyR receptors [13]. The S100A1, an important regulator of calcium cycling, revealed the modulated activity of RyR in calcium-dependent way. The model activation of calcium release by RyR receptor in both hearts and skeletal muscles included knock-out RyR inhibitor (CaM).

Earlier, we have shown that dephosphorylated 2'$5^{\prime} \mathrm{A}_{3}$ and its chemically modified analogues possess similar activity towards stimulating the $\mathrm{Ca}^{2+}$-currents inactivation kine tics in HVA cell cultures [14]. Other experimental results, obtained by us, demonstrate that 2'$5^{\prime} \mathrm{A}_{3}$ stimulates the RyR mediated $\mathrm{Ca}^{2+}$ release from the sarcoplasmatic reticulum in the smooth muscle cells [6].

Current report demonstrates the recently obtained experimental data, proving the possibility of interaction between the "core» 2'-5' $\mathrm{A}_{3}$ and human $\mathrm{S} 100 \mathrm{~A} 1$ protein in apo- $\left(\mathrm{Ca}^{2+}\right.$ free $)$ form.

Materials and methods. Synthesis of 2'-5'-linked oligoadenylates. Natural $2^{\prime}-5{ }^{\prime} \mathrm{A}_{3}$ and its epoxy modified analogue (2'-5' $\mathrm{A}_{3}$-epoxy) were synthesized from a solution modified by phosphotriether method [15] (Fig. 1).

Synthesis and purification of the recombinant human apo-S100A1. The synthetic gene encoding human S100A1 was cloned into pET-30a + plasmid and ex- 
pressed in Escherichia coli utilizing the T7 expression system. Bacterial cells were grown at $37^{\circ} \mathrm{C}$ in LB medium. Expression was induced by addition of $0.4 \mathrm{mM}$ IPTG at $\mathrm{OD}_{600}=0.8$. Bacterial culture was grown for $2 \mathrm{~h}$ afterward. Human S100A1 was isolated using the classical method of ammonium sulfate precipitation [16, 17] followed by the purification procedure using reversed-phase HPLC on a semi preparative Vydac C18 column [18]. The final product was identified by the electrospray ionization mass spectrometry using a Macromass Q-Tof spectrometer. The concentration in solution was estimated from its absorbance at $280 \mathrm{~nm}$. For the synthesis of the recombinant ${ }^{15} \mathrm{~N}$-labeled human $\mathrm{S} 100 \mathrm{~A} 1$ protein, the $E$. coli cells were grown in M9 media containing $\left({ }^{15} \mathrm{NH}_{4}\right)_{2} \mathrm{SO}_{4}$ as the sole nitrogen source and unlabeled glucose as the sole carbon source.

CD Spectroscopy. The far-UV CD spectra were recorded over 260-200 nm range on Jasco J-815 CD spectropolarimeter at $298 \mathrm{~K}$ in a $2 \mathrm{~mm}$ light path length cuvette. For the measurements, $8 \mu \mathrm{M}$ human $\mathrm{Ca}^{2+}$-free form of S100A1 protein (apo-S100A1) was dissolved in a buffer that contained $5 \mathrm{mM}$ Tris- $\mathrm{HCl}$ and $100 \mathrm{mM}$ $\mathrm{NaCl}(\mathrm{pH}$ 7.5). The concentration of human S100A1 in solution was controlled spectrophotometrically by measuring its UV absorbance at $280 \mathrm{~nm}$ using extinction coefficient $10200\left(\mathrm{~mol}^{-1} \mathrm{~cm}^{-1}\right)$ on Cary Eclipse spectrophotometer. The titration experiments were performed by adding the small amounts of natural 2'-5' $\mathrm{A}_{3}$ or 2'-5' $\mathrm{A}_{3}$-epoxy concentrated stock solution, prepared in the same buffer. The final oligoadenylate concentration was $56 \mu \mathrm{M}$.

The oligoadenylate-apo-S100A1 solution ellipticity values $[\theta]$ were corrected by subtracting the corresponding values for natural $2^{\prime}-5^{\prime} \mathrm{A}_{3}$ or 2'-5' $\mathrm{A}_{3}$-epoxy only and converted into the molar ellipticity $\left[\theta_{\text {molar }, \lambda}\right]$, using the following equation:

$$
[\theta]_{\text {molar }, \lambda}=\frac{100 \theta_{\lambda}}{m d},
$$

where $\theta_{\lambda}$ is the observed ellipticity (degrees) at wavelength $\lambda, m$ is the molar concentration of protein solution and $d$ is the path length in centimeters. The secondary structure content of human S100A1 was extracted using CDNN deconvolution software [19].

NMR Spectroscopy and S100A1 titration with 2'$5^{\prime} A_{3}$. All NMR data sets were acquired on Varian Unity + 500 NMR spectrometer $\left({ }^{1} \mathrm{H}\right.$ resonance frequency 500,606
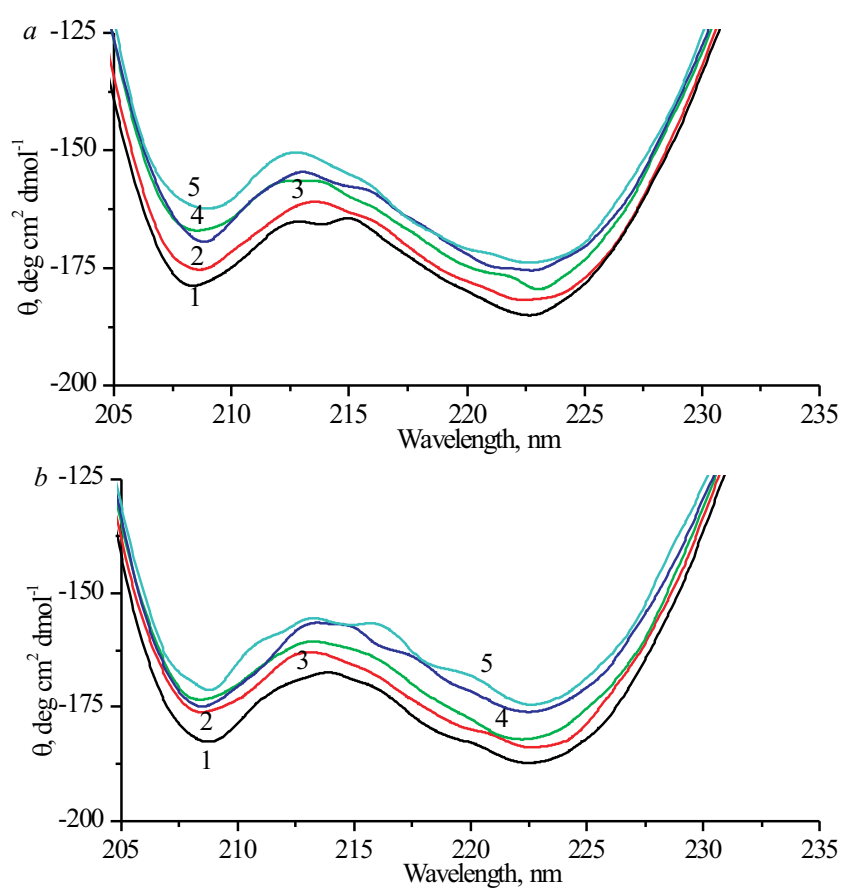

Fig. 2. CD spectra of Apo-S100A1 (black/1) in the presence of $8 \mu \mathrm{M}$ (red/2), $24 \mu \mathrm{M}$ (green/3), $40 \mu \mathrm{M}$ (blue/4) and $56 \mu \mathrm{M}$ (cyan/5) of 2'-5'A3-nat (a) or 2'-5'A3-epo (b).

$\mathrm{MHz}$ ) equipped with three channels, $z$-gradients unit and ${ }^{1} \mathrm{H} /{ }^{13} \mathrm{C} /{ }^{15} \mathrm{~N}$ triple resonance probe head with inverse detection. NMR sample was prepared by dissolving 0.3 $\mathrm{mM}{ }^{15} \mathrm{~N}$-labeled human apo-S100A1 protein in $90 \% /$ $10 \% \mathrm{H}_{2} \mathrm{O} / \mathrm{D}_{2} \mathrm{O}, 20 \mathrm{mM}$ TRIS-d 11 and $150 \mathrm{mM} \mathrm{NaCl}$ buffer solution. Spectra were recorded at $293 \mathrm{~K}$ using sodium 2,2-dimethyl-2-silapentane-5-sulfonate (DSS) as external indirect reference with coefficients $\Xi=$ $=0.251449530$ and $\Xi=0.101329118$ for ${ }^{13} \mathrm{C}$ and ${ }^{15} \mathrm{~N}$ resonance frequencies respectively [20]. In order to obtain the detailed information about the interaction between apo-S100A1 and 2'-5' $\mathrm{A}_{3}$, the concentrated stock solution containing $130 \mathrm{mM}$ of $2^{\prime}-5{ }^{\prime} \mathrm{A}_{3}$ was prepared in the same buffer. The NMR titration experiment was done as four consecutive injections ( $10 \mu \mathrm{L}$ each) of stock solution to previously prepared NMR sample. Every addition was followed by acquiring $2 \mathrm{D}{ }^{1} \mathrm{H}-{ }^{15} \mathrm{~N}$ HSQC spectra. All recorded data were processed with the NMR Pipe [21] and analyzed with the Sparky [22] software.

Results and discussion. CD spectroscopy. Far-UV circular dichroism (CD) in the 260-200 nm range is widely used for the protein structure analysis [23]. In case of human S100A1, the recorded CD spectrum demonstrates two strong bands at around 222 and 208 nm (Fig. 2, 
Changes in human apo-S100A1 protein's secondary structure content upon interaction with natural 2'-5' A3 or 2'-5'A -epoxy

\begin{tabular}{|c|c|c|c|c|c|c|}
\hline \multirow{2}{*}{$\begin{array}{c}\text { Concentration of } \\
\text { oligoadenylates, } \mu \mathrm{M}\end{array}$} & \multicolumn{3}{|c|}{$2^{\prime}-5^{\prime} \mathrm{A}_{3}, \%^{\mathrm{a}}$} & \multicolumn{3}{|c|}{$2^{\prime}-5^{\prime} \mathrm{A}_{3}$-ероху, $\%^{\mathrm{a}}$} \\
\hline & $\alpha$-Helix & $\beta$-Turn & Random coil & $\alpha$-Helix & $\beta$-Turn & Random coil \\
\hline 0 & 54.5 & 13.7 & 21.1 & 54.5 & 13.7 & 21.1 \\
\hline 8 & 53.2 & 13.9 & 21.7 & 52.9 & 13.9 & 21.8 \\
\hline 24 & 50.2 & 14.2 & 23.1 & 51.9 & 14.0 & 22.4 \\
\hline 40 & 49.8 & 14.3 & 23.4 & 50.6 & 14.2 & 23.0 \\
\hline 56 & 48.8 & 14.4 & 23.9 & 49.6 & 14.3 & 23.5 \\
\hline
\end{tabular}

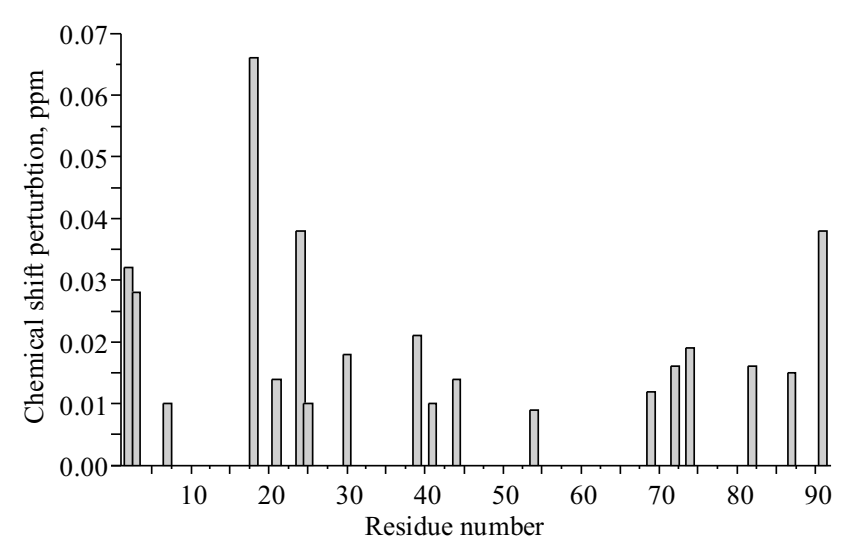

Fig. 3. $A$ - chemical shift perturbation (csp) plot on $2 \mathrm{D}{ }^{1} \mathrm{H}-{ }^{15} \mathrm{~N}$ HSQC spectra upon titration with $2^{\prime}-5^{\prime} \mathrm{A}_{3}$ (only residues with notable csp values are presented)

$a, b)$, which is an essential feature for the proteins with high content of $\alpha$-helical structure [24]. According to the literature sources, the 3D structure of apo-S100A1 homodimer is dominated by four long $\alpha$-helices with two short antiparallel $\beta$-sheets in C-terminal parts of both $\mathrm{Ca}^{2+}$-binding loops [25].

The secondary structure analysis revealed that more than $50 \%$ of the protein's secondary structure content is presented by $\alpha$-helical elements. The contents of $\beta$-turns and randomly coiled elements are very low (Table). The presented CD spectra are very similar to those previously obtained in our group or published for structurally similar S100B protein [26].

An addition of either natural $2^{\prime}-5^{\prime} A_{3}$ or its epoxymodified derivative to the protein solution did not provide any dramatic changes in initial protein $\mathrm{CD}$ spectra shape. Nevertheless, it is demonstrated that $2^{\prime}-5^{\prime} \mathrm{A}_{3}$ oligoadenylates caused tiny alterations in $3 \mathrm{D}$ structure reflected in a small decrease of molar ellipticity within both helical bands (Fig. 2, A, B). The analysis of apo-
S100A1 secondary structure demonstrated that addition of the oligoadenylate at maximum concentration, either natural or epoxy-modified, led to a decrease in the $\alpha$-helical conformation by $6 \%$ (Table). The value of error was determined by calculating the differences in evaluation of the secondary structure content within different regions of the $\mathrm{CD}$ spectra by the software. The value turned out to be around $2 \%$ at the average in all cases.

NMR spectroscopy of human apo-S100A1 protein and its titration with natural 2'-5' $A_{3}$ oligoadenylates. The high-resolution 3D structure of apo-S100A1 is presented as X-type homodimeric biomolecule. Each subunit has two helix-loop-helix $\mathrm{Ca}^{2+}$-binding EF-hand motifs of 93 amino acid residues. The spatial structure S100A1 in solution was solved independently by several groups under slightly different conditions (buffer, $\mathrm{pH}$, ionic strength) and temperatures which could lead to small differences in $\mathrm{Ca}^{2+}$ affinity $[25,27,28]$. In the present study, the NMR data sets were acquired on NMR sample containing $300 \mu \mathrm{M}$ of ${ }^{15} \mathrm{~N}$-labeled human apoS100A1 at pH 7.2 under the same conditions as we have used recently [28]. The sequence-specific assignments of ${ }^{1} \mathrm{H}$ and ${ }^{15} \mathrm{~N}$ resonances observed on $2 \mathrm{D}{ }^{1} \mathrm{H}-{ }^{15} \mathrm{~N}$ HSQC spectrum were transferred from previously deposited chemical shifts (bmrb code 18089).

A titration curve was obtained after four successive additions ( $10 \mu \mathrm{L}$ each) of $130 \mathrm{mM}$ natural 2'-5' $\mathrm{A}_{3}$ stock solution prepared in the same buffer. The chemical shift perturbations (csp) values were calculated from ${ }^{1} \mathrm{H}$ and ${ }^{15} \mathrm{~N}$ chemical shifts according to the following equation [29]:

$$
\Delta \sigma=\sqrt{0.2\left(\Delta \sigma_{N}\right)^{2}+}\left(\Delta \sigma_{H}\right)^{2} .
$$

An inspection of the ${ }^{1} \mathrm{H}$ and ${ }^{15} \mathrm{~N}$ HSQC NMR data sets exhibited several amino acid residues, which de- 


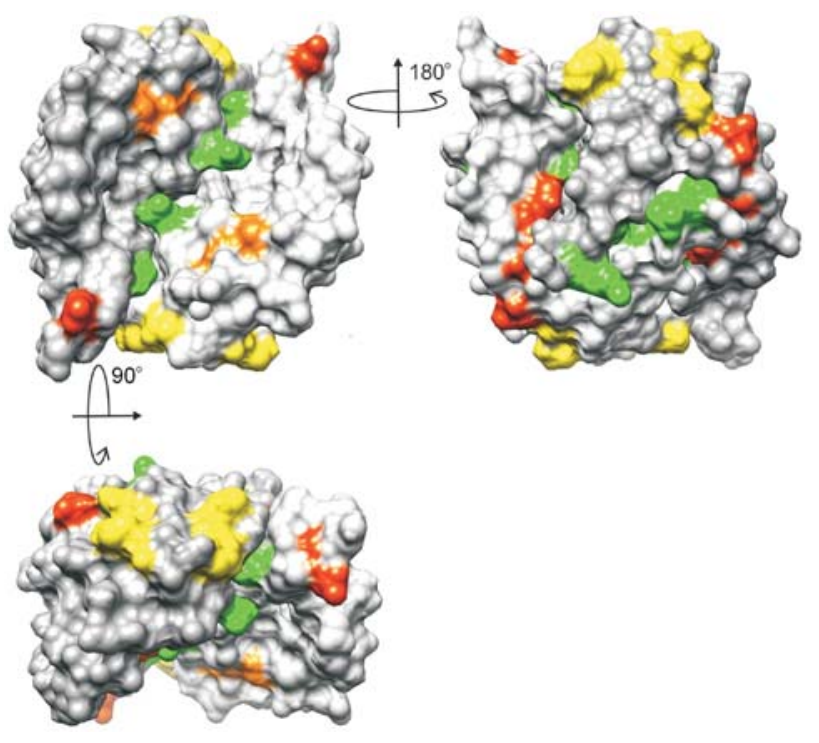

Fig. 4. Surface representation of 3D structure of human apo-S100A1 protein (pdb 2LLU) solved at the same experimental conditions [28] Residues exhibited notable csp are colored as follows: located within Nterminal (His 18, Lys21, Asp24, Lys25) and C-terminal (Val69, Gln72) $\mathrm{Ca}^{2+}$ - binding loops are highlighted in yellow and orange, respectively; residues within linker region and C-terminal part of helix IV (Glu39, Leu41, Phe44, and Glu91) are colored in red; at the intersubunit interface (Ser2, Glu 3, Ala7, Val54, Tyr74, Thr82, and Asn87) are highlighted in green

monstrated notable csp values for amide groups (Fig. 3, A). The recorded experimental data could be used to obtain information about binding constants of native 2'5 'A $\mathrm{A}_{3}$ oligoadenylates to apo-S100A1 [30]. The dissociating constants extracted from the chemical shifts curves (Fig. 3, $B$ ) fall in the moderate $10^{-5} \ldots 10^{-6} \mathrm{M}$ range suggested that the interaction of $2^{\prime}-5^{\prime} \mathrm{A}_{3}$ with the human apo-S100A1 protein is biologically relevant, but the specificity is not very high.

A comparison of the obtained results with known high-resolution 3D structure of the human apo-S100A1 $[27,28]$ gave us an idea about structural alterations caused by $2^{\prime}-5^{\prime} \mathrm{A}_{3}$ binding (Fig. 4). It turned out, that positions of the residues with higher csp values referred to the $\mathrm{Ca}^{2+}$-binding loops, which constituted the central part of the EF-hand domains. Majority of these signals came from the $\mathrm{N}$-terminal part of the $\mathrm{Ca}^{2+}$-binding motif (His18, Lys21, As 24, Lys25, Lys30), which was characterized by strong dependence on tiny changes in experimental conditions such as temperature, $\mathrm{pH}$ or/ and ionic strength of solution. The amino acid residues within the C-terminal region of the protein globule demonstrated lower csp values upon the interaction with
2'-5' $\mathrm{A}_{3}$-nat oligoadenylates: only Val69 and $\mathrm{G} \ln 72$ revealed notable csp values (Fig. 4). We suggest that even tiny structural alterations in those regions of the protein globule may cause changes in its $\mathrm{Ca}^{2+}$-affinity.

The linker region (Glu40-Val51), in addition to Cterminal helix IV, constitutes another important region of S100A1 globule, which is mostly responsible for the interaction with target proteins/peptides. For instance, amino acid residues within the linker region are responsible for the hydrophobic contacts formation in case of interaction between S100A1 protein and Ryanodine receptor [31]. Another example is the complex between S100A1 and TRTK12 peptide, derived from actin-capping CapZ protein, which is formed via the interactions with amino acids within the «hinge» region (Phe44, Leu45, Lys49) and helix IV (Ala84, Cys85, Phe88) [32].

We have recently shown that central position in the linker region is being held by Phe44, which forms the socalled thiol-aromatic switch that controls hydrophobic interactions within this part of the protein globule (linker-helix IV) [28]. Some of the amino acid residues, located in close proximity to Phe44, demonstrated high csp values in a response to native 2 '-5' $\mathrm{A}_{3}$ binding, namely Thr39, Glu40, and Phe44 itself (Fig. 3, A).

As it has been previously noted, specific structural changes at the position of Phe44 further propagated to the whole linker [33]. As a result, notable alterations occurred anywhere within the S100A1 globule. In particular, the conformational changes might lead to $\alpha$-helix shortening by 3-4 residues (one turn) within either the linker region [28, 33] or helix IV [25, 34]. It has recently been shown in our group, that similar structural modifications caused the increase of $\mathrm{Ca}^{2+}$ affinity and changes in cooperativity of $\mathrm{Ca}^{2+}$-binding process [28]. These effects might explain small fluctuations within the S100A1 $\alpha$-helical content upon binding natural 2'-5' $\mathrm{A}_{3}$ oligoadenylates and its epoxy derivative (Table).

As has been previously noted, the linker region together with helix IV contained several residues strongly conserved throughout the whole S100 family of proteins [28]. Comparison of the S100A1 epitops involved in the interaction process with natural $2^{\prime}-5^{\prime} \mathrm{A}_{3}$ revealed that at least some of them formed contacts with the target proteins $[31,32]$. This supports an idea that oligoadenylates might regulate interactions of Ca-signaling proteins within S100 family with their targets in the similar fashion. 
It worth mentioning, that our experimental data demonstrated the impact of $2^{\prime}-5^{\prime} \mathrm{A}_{3}$ on the homodimeric interface within S100A1 globule. Some residues exhibited higher csp values (Ser2, Glu3, Ala7, Tyr74, Thr82, Asn 87, and Glu91), were involved in the formation of hydrophobic intersubunit contacts between helices I/I' and IV/ IV' (Fig. 4). Considering a low value of solvent-accessible surface area of this particular region of the protein globule, we suppose that 2'-5' $\mathrm{A}_{3}$ does not directly bind to residues within intersubunit interface, but rather transmits the effect to homodimeric surface upon binding to $\mathrm{Ca}^{2+}$-binding loop or/and linker region. The similar effect has previously been reported for structurally similar S100B protein upon binding $\mathrm{Ca}^{2+}$ ions [35]. The tiny effect of $2^{\prime}-5$ ' $\mathrm{A}_{3}$ binding to the apo-S100A1 homodimer interface might serve as an additional natural element, involved in the regulation of $\mathrm{Ca}^{2+}$ transduction pathway.

Conclusions. In our study we have demonstrated that $2^{\prime}-5^{\prime} A_{3}$ can act as a compound, capable of altering the secondary structure of the human apo-S100A1 protein. Addition of both natural and epoxy-modified oligoadenylates triggered the decrease of its helical structure nearly to the same extent (around $6 \%$ ). We believe that the changes within its helical structure might trigger functional $\mathrm{Ca}^{2+}$ signal transduction regulation through tuning the function of human S100A1 protein. The presented experimental data obtained by CD and NMR spectroscopy exhibits tiny conformational alterations observed within the most important regions of the human apo-S100A1 globule caused by natural 2'-5' $\mathrm{A}_{3}$ and its epoxy-modified derivative.

Our results suggested a possible implication of oligoadenylates in the regulation of the of S100A1 protein functioning.

Acknowledgments. Authors would like to acknowledge L. Zhukova for technical assistance with preparation of different forms of recombinant human apoS100A1 protein, Dr. G. Goch for assistance and expertise with CD measurements and Dr. I. Dubey for synthesizing the $2^{\prime}-5^{\prime} \mathrm{A}_{3}$-linked oligoadenylates. This work is partially supported (for IZ) from the Polish National Centre for Research and Development under research grant number 178479 (contract number PBS1/A9/13/ 2012).

The used equipment was sponsored in part by the Centre for Preclinical Research and Technology (CePT), a project co-sponsored by European Regional Development Fund and Innovative Economy, The National Cohesion Strategy of Poland.

Вивчення впливу дефосфорильованих 2'-5' олігоаденілатів на конформацію білка аро-S100A1 методами гетероядерного ЯМР та кругового дихроїзму

О. Ю. Скоробогатов, Д. М. Ложко, І. Ю. Жуков, О. В. Козлов, 3. Ю. Ткачук

Резюме

Низькомолекулярні медіатори природного походження - 2'-5' олігоаденілати - відіграють важливу роль в антивірусному механізмі, пов'язаному з інтерфероном, вони причетні до росту клітин, апоптозу та інших важливих процесів, щуо протікають у клітині. Зважаючи на значну кониентрацію 2'-5' олігоаденілатів всередині живої клітини, можна припустити, щяо вони слугують додатковими біологічно активними субстратами $і$ здатні регулювати функиіонування білка S100A1 in vivo. Mета. Пошук доказів можливості взаємодії 2'-5' олігоаденілатів з апо-формою білка S100A1 людини. Методи. Використано методи ЯМР і КД. Результати. Отримані дані вказують на те, щзо внаслідок взаємодії між 2'-5' олігоаденілатами та $\$ 100 A 1$ відбуваються перебудови у вторинній структурі останнього. Крім того, вдалося визначити, які саме амінокислотні залишки беруть учать у иій взаємодії. Висновки. Ймовірно, 2'-5' олігоаденілати є додатковими елементами складної системи регуляиії процесів, опосередкованих іонами $\mathrm{Ca}^{2+}$.

Ключові слова: 2'-5' олігоаденілати, S100A1.

Изучение влияния дефосфорилированных 2'-5' олигоаденилатов на конформацию белка аро-S100A1 методами гетероядерного ЯМР и кругового дихроизма

А. Ю. Скоробогатов, Д. Н. Ложко, И. Ю. Жуков, А. В. Козлов, 3. Ю. Ткачук

Резюме

Низкомолекулярные медиаторы природного происхождения 2'-5' олигоаденилаты - играют важную роль в антивирусном механизме, связанном с интерфероном, они причастны к росту клеток, апоптозу и другим важным прочессам, происходящим в клетке. Учитывая концентрацию 2'-5' олигоаденилатов внутри живой клетки, можно предположить, что они служат дополнительными био логически активными соединениями, способными регулировать функиионирование белка S100A1 in vivo. Цель. Поиск доказательств возможности взаимодействия 2'-5' олигоаденилатов с апо-формой белка S100A1 человека. Методы. Использованы методы ЯМР и КД. Результаты. Полученные данные указывают на то, что в итоге взаимодействия между 2'-5' олигоаденилатами и белком S100A1 происходят изменения вторичной структуры последнего. Кроме того, удалось определить аминокислотные остатки, непосредственно участвующие в этом взаимодействии. Выводы. Вероятно, что 2'-5' олигоаденилаты являются дополнительными элемен тами сложной системы, регулирующей процесcbl, опосредованные ионами $\mathrm{Ca}^{2+}$.

Ключевые слова: 2'-5' олигоаденилаты, S100A1. 


\section{REFERENCES}

1. Player MR, Torrence PF. The 2-5A system: modulation of viral and cellular processes through acceleration of RNA degradation. Pharmacol Ther. 1998;78(2):55-113.

2. Silverman $R H$. A scientific journey through the 2-5A/RNase L system. Cytokine Growth Factor Rev. 2007;18(5-6):381-8.

3. Liang SL, Quirk D, Zhou A. RNase L: its biological roles and regulation. IUBMB Life. 2006;58(9):508-14.

4. Malmgaard $L$. Induction and regulation of IFNs during viral infections. J Interferon Cytokine Res. 2004;24(8):439-54.

5. Pat. USA 5571799. (2'-5') olygoadenylate analogues useful as inhibitors of host-vs. graft response. Z Tkachuk, E Kvasyuk, G Matsuka, I Mikhailopulo I. Appl. 1991; publ. 1996.

6. Filippov I, TkachukZ, Dubei I. Mechanisms of vessel tone regulation by 2'-5'-oligoadenylates. Dopovidi Akad Nauk Ukrainy. 2010; 6:152-156.

7. Tkachuk ZIu, Dubei LV, Tkachuk VV, Tkachuk LV, Losyts'kyi MIu, Iashchuk VM, Dubei IIa. Study of the interaction of 2'-5'oligoadenylates and their analogues with proteins by fluorescence spectroscopy. Ukr Biokhim Zh. 2011;83(1):45-53.

8. Levchenko SM, Rebriev AV, Tkachuk VV, Dubey LV, Dubey IYa, Tkachuk ZYu. Studies on interaction of oligoadenylates with proteins in vitro by MALDI-TOF mass spectrometry. Biopolym Cell. 2013;29(1):42-8.

9. TkachukZ, Dubey I, Tkachuk L, Dubey L, Shlykov S, Babich L. The effect of 2'-5'-oligoadenylates on calcium binding to Calmodulin. $17^{\text {th }}$ Int. Symp on $\mathrm{Ca}^{2+}$-Binding Proteins and Calcium Function in Health and Disease. 2011; 41.

10. Jaremko L, Jaremko M, Elfaki I, Mueller JW, Ejchart A, Bayer P, Zhukov I. Structure and dynamics of the first archaeal parvulin reveal a new functionally important loop in parvulin-type prolyl isomerases. J Biol Chem. 2011;286(8):6554-65.

11. Zimmer DB, Chaplin J, Baldwin A, Rast M. S100-mediated signal transduction in the nervous system and neurological diseases. Cell Mol Biol (Noisy-le-grand). 2005;51(2):201-14.

12. Prosser BL, Hernandez-Ochoa EO, Lovering RM, Andronache $Z$, Zimmer DB, Melzer W, Schneider MF. S100A1 promotes action potential-initiated calcium release flux and force production in skeletal muscle. Am J Physiol Cell Physiol. 2010;299(5): C891-C902.

13. Wright NT, Prosser BL, Varney KM, Zimmer DB, Schneider MF, Weber DJ. S100A1 and calmodulin compete for the same binding site on ryanodine receptor. J Biol Chem. 2008;283(39):26676-83.

14. Kostyuk PG, Kozlov AV, TkachukZYu, Viatchenko-Karpinksi SV, Sedova MV, Mikhaikopulo IA, Kvasyuk VI, Tselenko VI. Effect of «core» 2'5'-oligoadenylates on the phosphorylation-dependent calcium channels in GH3 cells. Ukr Biokhim Zh. 1995;67 (1):26-32

15. Dubey $I Y a$, Dubey $L V$. Synthesis of $\left(2^{\prime}-5^{\prime}\right)$-triadenylate and their analogues using O-nucleophilic catalysis of internucleotide coupling reaction. Biopolym Cell. 2007; 23(6):538-44.

16. Dixon $M, W e b b E C$. Enzyme fractionation by salting-out: a theoretical note. Adv Protein Chem. 1961;16:197-219.

17. Falconer JS, Jenden DJ, Taylor DB. The application of solubility measurements to the study of complex protein solutions and to the isolation of individual proteins. Discuss Faraday Soc. 1953; 13:40

18. Bolewska K, Kozlowska H, Goch G, Mikolajek B, Bierzynski A. Molecular cloning and expression in Escherichia coli of a gene coding for bovine S100A1 protein and its Glu32-->Gln and Glu73--> Gln mutants. Acta Biochim Pol. 1997;44(2):275-83.
19. Bohm G, Muhr R, Jaenicke R. Quantitative analysis of protein far UV circular dichroism spectra by neural networks. Protein Eng. 1992;5(3):191-5.

20. Wishart DS, Bigam CG, Yao J, Abildgaard F, Dyson HJ, Oldfield E, Markley JL, Sykes BD. ${ }^{1} \mathrm{H},{ }^{13} \mathrm{C}$ and ${ }^{15} \mathrm{~N}$ chemical shift referencing in biomolecular NMR. J Biomol NMR. 1995;6(2):135-40.

21. Delaglio F, Grzesiek S, Vuister GW, Zhu G, Pfeifer J, Bax A. NMR Pipe: a multidimensional spectral processing system based on UNIX pipes. J Biomol NMR. 1995;6(3):277-93.

22. Goddard TD, Kneller DG. SPARKY 3. San Francisco, University of California publ., 2004.

23. Kelly SM, Price NC. The use of circular dichroism in the investigation of protein structure and function. Curr Protein Pept Sci. 2000;1(4):349-84.

24. Johnson $W C J r$. Protein secondary structure and circular dichroism: a practical guide. Proteins. 1990;7(3):205-14.

25. Rustandi RR, Baldisseri DM, Inman KG, Nizner P, Hamilton SM, Landar A, Landar A, Zimmer DB, Weber DJ. Three-dimensional solution structure of the calcium-signaling protein apo-S100A1 as determined by NMR. Biochemistry. 2002;41(3):788-96.

26. Ferguson PL, Shaw GS. Role of the N-terminal helix I for dimerization and stability of the calcium-binding protein $\mathrm{S} 100 \mathrm{~B}$. Biochemistry. 2002;41(11):3637-46.

27. Nowakowski M, Jaremko L, Jaremko M, Zhukov I, Belczyk A, Bierzynski $A$, Ejchart $A$. Solution NMR structure and dynamics of human apo-S100A1 protein. $J$ Struct Biol. 2011;174(2):391-9.

28. Lenarcic Zivkovic M, Zareba-Koziol M, Zhukova L, Poznanski J, Zhukov I, Wyslouch-Cieszynska A. Post-translational S-nitrosylation is an endogenous factor fine tuning the properties of human S100A1 protein. J Biol Chem. 2012;287(48):40457-70.

29. Garrett DS, Seok YJ, Peterkofsky A, Clore GM, Gronenborn AM. Identification by NMR of the binding surface for the histidinecontaining phosphocarrier protein $\mathrm{HPr}$ on the N-terminal domain of enzyme I of the Escherichia coli phosphotransferase system. Biochemistry. 1997;36(15):4393-8.

30. Most P, Remppis A, Pleger ST, Katus HA, Koch WJ. S100A1: a novel inotropic regulator of cardiac performance. Transition from molecular physiology to pathophysiological relevance. Am J Physiol Regul Integr Comp Physiol. 2007;293(2):R568-77.

31. Prosser BL, Wright NT, Hernandez-Ochoa EO, Varney KM, Liu $Y$, Olojo RO, Zimmer DB, Weber DJ, Schneider MF. S100A1 binds to the calmodulin-binding site of ryanodine receptor and modulates skeletal muscle excitation-contraction coupling. $J$ Biol Chem. 2008;283(8):5046-57.

32. Wright NT, Cannon BR, Wilder PT, Morgan MT, Varney KM, Zimmer DB, Weber DJ. Solution structure of S100A1 bound to the CapZ peptide (TRTK12). J Mol Biol. 2009;386(5):1265-77.

33. Groves $P$, Linse $S$, Thulin E, Forsen $S$. A calbindin D9k mutant containing a novel structural extension: ${ }^{1} \mathrm{H}$ nuclear magnetic resonance studies. Protein Sci. 1997;6(2):323-30.

34. Nowakowski M, Ruszczynska-Bartnik K, Budzinska M, Jaremko L, Jaremko M, Zdanowski K, Bierzynski A, Ejchart A. Impact of calcium binding and thionylation of S100A1 protein on its nuclear magnetic resonance-derived structure and backbone dynamics. Biochemistry. 2013;52(7):1149-59.

35. Marlatt NM, Shaw GS. Amide exchange shows calcium-induced conformational changes are transmitted to the dimer interface of S100B. Biochemistry. 2007;46(25):7478-87.

Received 26.02.14 